\title{
Claude Le Jeune and Theodore de Bèze: A first encounter in the Dix Pseaumes ... en forme de Motets of 1564
}

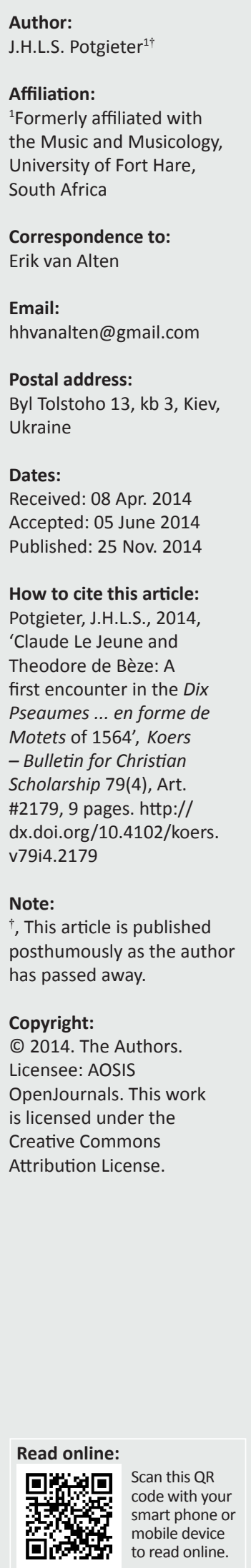

In this article Claude Le Jeune's Dix Pseaumes is investigated, with special attention to its historical context. The Dix Pseaumes came into existence during the initial phase of the French wars of religion, between the Edict of Ambois on 19 March 1563 and its publication in 1564, with Le Jeune as its composer and Theodore de Bèze wrote the texts. De Bèze's influence in forming the French Protestant's view on armed resistance makes his connection to the Dix Pseaumes very interesting. It is argued that the non-sequential order of the psalms in this work cannot be accepted as unintentional, but relates directly to the political situation of that time. The texts were evidently chosen to mirror a well-defined consciousness of the French Protestants' particular existential situation. This is worked out in detail with respect to the opening psalm (Psalm 96), but can be detected in all the other psalms as well. The closing psalm (Psalm 81) ends with an upbraiding of the people's unkindness in refusing the yoke of God's law. Thus the obstinate disobedience of the people is blamed for the sad state of affairs in the country. This sorrowful note is echoed in the chanson spirituelle, Mais qui es-tu, which closes Le Jeune's collection.

Claude le Jeune en Theodore de Bèze: 'n Eerste ontmoeting in die Dix Pseaumes ... en forme de Motets van 1564. In hierdie artikel word Claude Le Jeune se Dix Pseaumes ondersoek, met spesiale aandag vir die historiese konteks. Die Dix Pseaumes het ontstaan tydens die beginfase van die Franse Godsdiensoorloë, tussen die Edik van Amboise op 19 Maart 1563 en die publikasie van die Dix Pseaumes in 1564. Le Jeune was die komponis en Theodore de Bèze het die tekste berym. Laasgenoemde se invloed op die Franse Protestante se visie op gewapende weerstand maak sy verbintenis met die Dix Pseaumes besonder interessant. In hierdie artikel word geargumenteer dat die psalms in hierdie werk doelbewus in 'n nie-opeenvolgende orde geplaas is, en dat dit saamhang met die politieke situasie van daardie tyd. Dit is duidelik dat die tekste gekies is om die bewussyn van die Franse Protestante se besondere situasie te reflekteer. Dit word in besonderhede uitgewerk met betrekking tot die openingspsalm (Psalm 96), maar kan ook in die ander psalms waargeneem word. Die slotpsalm (Psalm 81) sluit af met 'n vermaning oor die volk se onbedagsaamheid omdat hulle God se juk weerstaan het. Die hardnekkige ongehoorsaamheid van die volk word geblameer vir die hartseer toestand in die land. Hierdie droewige noot vind weerklank in die geestelike lied, Mais qui es-tu, waarmee Le Jeune se versameling afgesluit word.

\section{Introduction}

Although Claude Le Jeune (ca. 1528-1600) is a towering figure in French Renaissance music, relatively few biographical details have survived the turmoil of his time. In order, therefore, to arrive at a more complete picture of his life and works, the general historical and spiritual background, implicating considerable circumstantial evidence, has to be considered more intensely than usual. The researcher is guided along this often nebulous road by two dominating beacons in Le Jeune's life, namely, his association with Jean-Antoine de Baïf's Académie de Poesie et de Musique, the focal point of French Musical Humanism, and his allegiance to the Reformed Faith, the latter involving close connections to leading Huguenot figures. Our deliberations will focus mainly on the latter aspect of Le Jeune's life. In fact, his works reveal an extraordinary engagement in the events of his time, inasmuch as these circumstances are consciously reflected in his music, one reciprocally elucidating the other. However, both these aspects need to be recognised and, as far as possible, made concrete in a responsible manner.

\section{Historical background}

Originally hailing from Valenciennes in the then Spanish Netherlands, Claude Le Jeune emanated from a family already rooted in the new faith and actively involved in the establishment of the Reformed Church from the time of Guy de Bres' ministry in that town. 
After an assumed sojourn in Italy during the 1550s probably in the circle around the ageing Willaert in Venice - he decided to settle in Paris, where he spent most of his remaining life. However, besides Italy, something else of great importance took place in Claude Le Jeune's life during the late 1550s or the early 1560s: during this time he linked up with the families of leading Huguenot figures who patronised him and gave him much-needed protection during the turbulent years of religious wars in France. The contact with his influential fellow-believers could have been established before or after his Italian sojourn; it was certainly intensified after that visit.

For sure, the possibility of such contact was created when, in 1552, Henry II concluded a treaty with the German Protestant princes against Charles $\mathrm{V}$, in consequence of which he took possession of Metz, Toul, and Verdun, and French forces invaded Hainaut. From this time onwards until Coligny's defeat at Saint Quentin in 1557, a major part of French foreign political interest was concentrated on the southern Netherlands. This brought about a more or less permanent presence of French military forces with young nobility in their ranks, eager to deserve well in war and gain honour for themselves.

Indeed, under the influence of his brother, François d'Andelot, Coligny finally and publicly converted to Protestantism only during his imprisonment after the battle of Saint Quentin. It can, however, not be overlooked that many of the young nobility who served under him already confessed to the new faith, or were, at least, cryptoProtestants. In this regard the names of the admiral's sonin-law, Charles de Téligny, and his friend of about the same age, François de la Nouë, ${ }^{1}$ come to mind. Both later assumed prominent roles amongst the Huguenot leaders. Both also very soon figured in Le Jeune's life: he dedicated the first collection of compositions which appeared entirely under his own name - the Dix Pseaumes ... en forme de Motets of $1564^{2}$ - jointly to them in recognition of l'affection et obligation que j'ay a vostre service. ${ }^{3}$ Moreover, Le Jeune testified in 1585 that he had actually been La Nouë's music teacher, ${ }^{4}$ a fact which also points to the years in question here. It is, therefore, conceivable that Le Jeune had spent an interlude on the Breton estate of the La Nouë family before he went to settle in Paris, more or less at the time of the publication of his Dix Pseaumes.

Thus the composer emerged at the beginning of the sixties of that great age of spiritual surge and religious regeneration as an individual well wrought by the events of his time: not gaining a provincial living in the stagnancy of intellectual

1. He was born in 1531 and, like Coligny, converted to Protestantism in 1558

2.Dix Pseaumes de David, novvellement composez a qvatre parties en forme de motets. Auec vn Dialogue a scept, par Claudin Lejeune ... (see Le Jeune 1564).

3.Dix Pseaumes (Le Jeune 1564): Letter of dedication. For the sake of authenticity, punctuation marks are used only where these occur in the original documents.

4.Livre de Melange (Le Jeune 1585): Dedication to Odet de la Noue (son of François), ... ie me suis adresse a V.S., estant esquillonne du bon naturel qu'elle a de ses tant nobles et vertueux parens, avec la promte inclination a ceste science, laquelle i'ay apperceue en luy proposant les premiers rudimens. backwaters, but, precast by the religious situation of his northern homeland, inspired by redeeming musical ideas from the south, and conscious of the protection of prominent political figures, he set out to establish himself in the French capital, aspiring to deserved recognition. A coup d'oeil of the historical scene at that time may prove advantageous to our further deliberations.

We do not know with certainty exactly when Claude Le Jeune arrived in Paris with the intention of settling there. It can, however, be assumed to have occurred not later than $1567,{ }^{5}$ but, most probably, three years earlier, when his Dix Pseaumes ... en forme de Motets were published by Adrian Le Roy and Robert Ballard, or even somewhat prior to that. On the other hand, it is questionable whether Le Jeune would have settled in Paris at a very much earlier date $^{6}$ - the reason for this being that Henry II, after the conclusion on 02 April 1559 at Château Cambresis of the peace treaty with Spain, regarded the elimination of the French Protestants as his prime task. ${ }^{7}$ After his unexpected death this policy was pursued with even greater ardour and consequence by Charles de Guise, Cardinal of Lorraine, in whom Francis II - still a youth when he ascended to the throne - invested practically all power of state.

However, when Guise attempted to infringe upon the authority of the Queen Mother, who acted as regent for her minor son (the new King Charles IX), Catherine de Medici, rightly fearing for the throne of the Valois, sought to assert herself with the support of the Protestant leaders Condé and Coligny. This manoeuvre provoked the Guise party to increase its assaults on the Huguenots (as the French Protestants now came to be called), contributing as they did to a mounting spirit of confrontation that led, ultimately, to the armed clashes of 1562 and 1563, which triggered off open civil war in France.

It can certainly be reasoned that such circumstances must have made it equally unsafe for a composer of the Reformed faith to reside in Paris. Yet, on the other hand - and in spite of this state of affairs - a Reformed congregation actually existed and was ministered to in the capital by, amongst other ministers Antoine de la Roche-Chandieu, François Morel and Jean Le Macon. Le Jeune could hardly have been more exposed than these, who were all known for their involvement in an urge amongst many French Protestants of the day towards greater radicalism. This attitude, bearing marked political overtones, was directed mainly against the Guise Party, which now came to be considered a usurpative force, undermining both the faith and the kingdom.

5.According to the Charter of Jean-Antoine de Baif's Academie de Poësie et de Musique, with which Le Jeune was closely associated since its inception in 1570 work on this enterprise started about three years previously: ... depuis trios ans en ca avroient avec grande estude et labeur assiduel unanimement travaille.

6. Rene Vannes (n.d.:239), maintains that Le Jeune had his first chansons published in Paris in 1544, and that he remained there ever since. Quite evidently he confused Le Jeune with the older Claudin de Sermisy.

7.See Von Ranke (1957:95). Indeed, the papal nuncio in Brussels reported on 17 May, 1559 to Rome that Sa Majeste tres christienne ne veut plus s'occuper 17 May, 1559 to Rome that Sa Majeste tres christienne ne veut plus s'occuper
desornais d'autre chose dans son royaume, que d'extiper l'heresie (see Doumergue 1899-1927:197-198, 241). 
Although Calvin warned against this trend towards radicalism and insurrection against authority (Nürnberger 1948:35-36, 50, 92-93), the spirit of resistance amongst French Protestants, duly fanned by the views of Hotman and associates (Nürnberger 1948:86, 94), gathered momentum and characterised further developments which led to the illfated conspiracy of Amboise in March 1560 and the eventual outbreak of Civil War.

We shall probably never be quite sure about Claude Le Jeune's exact movements during this particular point in time. As mentioned earlier, he could have enjoyed the safety and protection offered by his noblemen patrons and fellowbelievers on their northern estates. Or he could, instead, have moved within the walls of the capital, where he hoped to accomplish fame as a composer. We can, however, be sure of one thing: Le Jeune appears to have been closely associated with the events of these turbulent years, an involvement reflected in several pieces of complementary evidence that add eloquently to the biographical picture of the composer. Before advancing these, we must yet cast our eyes back to the general historical scene.

When the Queen Mother decided to continue her entente with the Protestants even after the assassination of François de Guise, it was by no means her intention to allow the Reformed faith to establish itself on a broad basis in France. Political opportunism much rather caused her to decree the Edict of Amboise on 19 March 1563. This edict guaranteed to the Huguenots a considerable measure of tolerance. Even though the edict did not grant the Protestants everything they had strived for, it nevertheless allowed them to erect their churches under the protection of the law and to develop an ecclesiastical way of life according to the example of Geneva.

At this stage, attention is focused on Claude Le Jeune by the publication in 1564 of his Dix Pseaumes.

\section{Background to Dix Pseaumes}

The dedication of this collection suggests that the composer - as mentioned above - enjoyed the protection of Huguenot patrons for some time preceding its publication. He dedicated the set of compositions to François de la Nouë and Charles de Téligny ${ }^{9}$ in return for l'affection et obligation que j'ay a vostre service, a cause de bienfais qu'ordinairement je recoy de vostre liberalite ... From the dedication we also learn that Le Jeune was intent not to delay the publication of his Dix Pseaumes but, aprez l'obscur et facheux temps qu'avons veu durant ces troubles passez - a clear reference to the unrest which followed upon the abortive religious Colloquy of Poisy - to come out in print with those available: Je n'ay voulu faire le long a publier ce que j'eu avoy de composes ...

8.In the war against Spain de la Nouë proved himself also in Piemont. After the conclusion of the Peace Treaty of Château Cambresis, he retired to his estates in Bretagne (cf. Haag \& Haag 1859:280 seq.; Moreri [1674] 1716:39), from where he played an important role in the disputes during the wars of religion. He married Marguerite de Teligny, the sister of his friend, Charles de Teligny.

9.Protégé and later son-in-law of the Admiral de Coligny, together with whom he was murdered in Paris on the night of Saint Bartholomew, 1572.
It would, therefore, seem that the Dix Pseaumes were only the first of more psalm compositions Le Jeune intended to produce in this or similar vein. Indeed, ultimately almost half of his extant 659 works are based on the Huguenot Psalter, not including the Dix Pseaumes and the 24 Psalm texts of his Pseaumes en vers measures, ${ }^{10}$ which do not employ the Genevan melodies. Curiously enough, 34 years would pass after the publication of 1564 before another collection of psalm settings, the Dodecacorde of $1598,{ }^{11}$ emerged from the press. L'injure du temps, to which Le Jeune also refers in the dedication (to Odet de la Nouë) of his Livre de Melange of 1585, may well be responsible for this lapse of time. Evidently, many of his psalm settings - mostly published posthumously - were written during the later decades of his life. Noteworthy at this stage is the fact that Claude Le Jeune engaged himself from an early point in his career with the psalms, and that this particular interest was maintained throughout his entire life.

From Le Jeune's remarks in the dedication of his Dix Pseaumes it becomes clear that he must have devoted himself to the composition of the collection in the period between the proclamation of the Edict of Amboise (19 March 1563) and the year of publication (1564).12 Of equal importance is the fact that all the texts of the Dix Pseaumes are by Theodore de Bèze, Calvin's right hand and eventual successor in Geneva, and also the leader of the Protestant side at the Colloquy of Poissy. The psalms in question are (in sequence of their appearance in the collection):

$\begin{array}{ll}96 & \text { Cantate Domino } \\ 102 & \text { Domine exaudi orationem } \\ 135 & \text { Laudate nomen Domini } \\ 88 & \text { Domine Deus salutis } \\ 57 & \text { Miserere mei Deus, Miserere } \\ 98 & \text { Cantate Domino canticum } \\ 149 & \text { Cantate Domino } \\ 95 & \text { Venite exultemus } \\ 97 & \text { Dominus regnavit } \\ 81 & \text { Exultate Deo adiuto }\end{array}$

Followed by a chanson spirituelle, Mais qui es-tu, a dialogue for seven voices.

Except for Psalm 57, the text of which had appeared in $1554^{13}$ as one of the Appendix Psalms added to the tunes of the psalms already included in the 1552 edition, ${ }^{14}$ all the other psalm texts employed by Le Jeune were entailed for the first time in the complete psalter, published simultaneously in 10.Pseaumes en Vers mesurez mis en musique a 2.3.4.5.6.7. \& 8 parties (Le Jeune 1606).

11.Dodecacorde contenant douze Pseaumes de David, mis en musique selon les douze modes approuvez des meilleurs Autheurs anciens \& modernes a 2.3.4.5.6. et 7 voix (Le Jeune 1598).

12.Since no dated Letter of Privilege is attached to the Dix Pseaumes, and with the dedication also undated, the exact month of publication cannot be pin-pointed.

13. Octante trios Pseaumes de David, mis en rime François: A scavoir Quaranteneuf par Clement Marot, auec la Cantique de Simeon \& les dix commandemens: Et trente quatre par De Bèze (1554)

14.Pseaumes octante trios de Dauid miz en rithme François e. A scauoir, quarante neufpar Clement Marot auec le Cantique de Simeon et les dix Commandemens. Et trente quatre par De Bèze (1552) 
Geneva and Paris in $1562 .{ }^{15}$ Considering the relatively short period of time that elapsed since their appearance in print and their use in the Dix Pseaumes, these texts could only have been available to Le Jeune in a pronounced, perhaps even ecclesiastically organised Reformed circle. Such company could - as, indeed, the Dedication to François de la Nouë and Charles de Téligny suggests - be expected in the proximity of the Huguenot leaders Condé and Coligny, but equally well amongst some of the activist ministers mentioned earlier. For sure, since Theodore de Bèze repeatedly visited the Huguenot leaders and ministers at that time, it is quite possible that he had brought the texts to France himself!

In this connection it is of more than passing interest to note that De Bèze was initially - before he was persuaded to accept Calvin's view on the matter - not averse to the idea of an insurrection against the Guise (Naef 1922:113, 217 seq.). This was borne out by evidence which surfaced at two rather intriguing court cases conducted in Geneva during the 1560s, the motive of which had been to establish the possible involvement of Calvin and the Genevan pastors in the abortive coup of Amboise. Clearly, the city's Council was (for political reasons) more than anxious to disavow any connection to such design (Nürnberger 1948:93).

Although Calvin and the pastors could not be blamed as accessories to Amboise, the issue was also not quite resolved. One of the details offered in testimony against De Bèze revealed that he had given his translation of Psalm 94 (the so-called 'vengeance Psalm') to La Renaudie, the head of the insurgents of Amboise, supposedly as a sign of his sympathy for their views. However, De Bèze excused himself by stating that he had also given La Renaudie other psalms (Nürnberger 1948:94). The impression nevertheless remained that he, at least initially, shared the views of the French activist ministers. Be that as it may, it would seem that he actually did provide copies of his translations of some of the psalms to the circles of activists in the orbit of which Claude Le Jeune appears to have moved. For, undoubtedly, the composer's connection with La Roche-Chandieu, ${ }^{16}$ whose Octonaires de la Vanite et Inconstance du Monde he later set to music, dates from this period.

Consciously establishing a connection between the Dix Pseaumes and the events in France preceding its publication, Le Jeune (referring to these compositions) says: ... pour laquel employer je n'eusse sceu chosis plus digne subject que cestuy-cy qui est de certaines pseaumes du divin poet $\mathcal{E}$ prophet David, lesquels j'ay mis en musique. ${ }^{17}$ A selective motive is thus clearly recognisable. Isabelle His (2000:83) suggests that the choice of Le Jeune's psalms might have been put forward by the publishers, since they had brought out a collection of

15.Les Pseaumes mis en rime Françoise, Par Clement Marot, \& Theodore de Bèze Pseaume IX, Chantez au Signeur qui habite en Sion, \& annoncez ses faits entre les peuples ... François Jaquy, Genève, 1562; Les cent et cinquante Pseaumes de David, mis en ryme Françoise: c'est a scavoir, quaranteneuf par Clement Marot, \& le surplus par Theodore de Bèze. ... Richard Breton, Paris, 1562.

16.It may also be noted that the brother of La Roche-Chandieu, Bertrand, belonged to the closest followers of La Renaudie.

17.Dix Pseaumes, Letter of Dedication. settings by Claude Goudimel just two years earlier which did not include the texts set to music by Claude Le Jeune. Surely, this opinion can lay claim only to an 'educated guess'. The fact is that Le Roy \& Ballard published in the very same year (1562) another collection of ten psalm settings by Goudimel, all of which but one had already appeared in the earlier set. Therefore, if a need existed to supplement the earlier edition with texts which were not included in it, why then repeat those which did in the new collection? Rather, one should not lose sight of the possibility of Le Jeune having received suggestions or even guidance from within the circle of activist ministers - perhaps even from De Bèze himself ${ }^{18}$ regarding his choice of the specific psalms together with the exegetical connotations attached to them.

\section{Psalm 96}

A deliberate choice is especially evident in the case of Psalm 96, which opens the collection. In essence this psalm is a hymn of praise. But had this property - appropriate as it surely is for an opening piece - been the sole reason for its selection, Le Jeune could have used any other of a number of psalms with the same tenor. Indeed, there appears to have been a valid reason for his choice of Psalm 96 to open the collection.

In this regard, a salient point, supporting my belief of a conscious and intended selective motive, must be advanced here, namely, a comparison with the re-edition of the Dix Pseaumes of 1580 . In this edition - besides minor musical (mostly cadential) adjustments to conform to then current fancies, as well as a major printing correction - important and conspicuous omissions deserve special mention, namely, the dedication to François de la Nouë and Charles de Téligny (the latter a victim of the St. Bartholomew massacre), as well as the chanson spirituelle Mais qui es-tu. All of this was, one cannot fail to suspect, due to the changed political situation prevailing around 1580, assuredly an oblique confirmation of the assumed intention in the original edition of $1564 .{ }^{19}$

But to return to the importance of Psalm 96 as an opening piece: this entire psalm, together with parts of Psalm 105 and Psalm $106,{ }^{20}$ is quoted in 1 Chronicles $16: 8-36$ as a Song of Praise, following upon David's victory over the Philistines in the Valley of Ephraim. ${ }^{21}$ A construed parallelism between this particular event in the history of Israel and occurrences in France becomes quite conspicuous if, considering the

18.From the outbreak of open Civil War De Bèze followed the Huguenot army: ... dans laquelle il fut charge des functions d'aumonier et de tresorier ... (Haag \& Haag 1859:267) and, undoubtedly, also as field chaplain. It is, therefore, conceivable that contact with Le Jeune could quite easily have been established.

19. Regarding this, one is reminded of the activities of the Potitiques, a party rallied around Henri de Montmorency as a retarded reaction against the atrocities of St Bartholomew and directed against the 'foreign faction' of the Guise, representing the interests of Spain (when it was preferred to speak of la guerre du bien public, instead of 'the war of religion'), in conjunction with the pursuits of the Duke of Anjou and Alencon in alliance with Huguenot leaders regarding the Netherlands. Anjou and Alencon in alliance with Huguenot leaders regarding the Netherlands. During this period Claude Le Jeune was actually included in the household of the head of a considerable force in 1582 .

20.Psalm 105:1-15, and Psalm 106:47-48, with some textual variants.

21.The victory over the Philistines is related in $1 \mathrm{Chr} .14: 8-17$ and is also referred to in $2 \mathrm{Sm} .5: 17-25$ 
apologetic frame of contemporary mind, one regards the unfolding of history prior to the Edict of Amboise.

With the power of state firmly in the hands of the Duc de Guise, and the young King Charles IX as well as the Queen Mother virtual prisoners of the Guise Party, many of the country's nobility - especially those with Protestant sentiments - gathered around the Princes of the Blood, notably Condé, who had successfully been manoeuvred away from the court and matters of state by the Guise. To these it became a matter of urgency to free the King and the Queen Mother from the grip of the 'usurpers'. Protestant ministers investigated whether it would be justified to take up arms in order to restore the legitimate authority and found it not only permissible, but a sacred duty to liberate the King and the Queen Mother, to defend the faith, and to restore previous edicts by which the Huguenots enjoyed some toleration of their religion (Von Ranke 1957:122). 'David consulted God; "Shall I attack the Philistines?" he asked. "Will you deliver them into my power?" Yahweh answered him, "Attack! I will deliver them into your power"' (1 Chr. 14:9-10).

In November of 1562 Condé had gathered enough Huguenot and foreign Protestant forces around him to risk an open confrontation. Intending to take Chartres and other towns along the Seine, he prepared to move towards the capital, a thrust which the Catholic allies had to prevent at all costs. They opposed him in the Plain of Dreux, and on 19 December 1562 battle was engaged. ${ }^{22}$ Although Dreux went down in military history as a defeat for the Huguenots, they were, however, far from considering themselves vanquished (Von Ranke 1957:124). 'Through me God has made a breach in my enemies like a breach the waters make' (1 Chr. 14:11). Indeed, not in the least thwarted, Coligny proceeded on his way to continue the war in Normandie:

David again consulted God and God answered, 'David, attack them from the front; go round and engage them opposite the balsam trees. When you hear the sound of steps in the tops of the balsam trees, launch your attack, for that will be God going ahead of you to rout the army of the Philistines'. (1 Chr. 14:14-15).

Thus the struggle was carried on with a firm belief in divine preordination and ultimate victory. ${ }^{23}$

But yet another facet of Psalm 96, equally serving the intimation of historical parallelism, can be taken to have contributed to its choice as the opening piece of the Dix Pseaumes. As a hymn of praise the psalm is distinctive ${ }^{24}$ in summoning to a new song in adoration of God. Calvin and Reformed exegesis of that time invariably explained the

22.For a description of the campaign and battle of Dreux, see Theodore de Bèze: ([1580] 1883:chap.6). Also, Jacques-August de Tou (1734:chap. 34).

23.See the letter of Coligny to Queen Elizabeth of England, quoted by Leopold von Ranke (1957:124): 'Unsere Infanterie hat eine Niederlage erlitten, ohne zu schlagen; unsere Reiterei, welche allein die Schlacht geliefert hat, ist unverletzt und wuenscht nichts mehr, als die Feinde Gottes und des Konigreichs bald wiederzusehen; diese nichts mehr, als die Feinde Gottes und des Konigreichs bald wiederzusehen; diese
werden sich besinnen, uns anzugreifen oder den Angriff von unserer Seite zu werden sich

24.This distinction is shared by Psalms 33, 40, 98 and 149. The expression 'new song' also occurs in Isaiah 42:10 and Revelations 5:9, and 14:3. epithet to denote something unwonted and remarkable, often pointing to the extraordinary grace of God in the deliverance of his people. Thus Calvin connects Psalm 96 with Isaiah 42:10 when he says: '... Quemad-modum Iesaias ubi de instauratione Ecclesiae loquitur, quia incredibile erat miraculum, dicit, Cantate Domino canticum novum.' (Calvin 1610:451). Indeed, within the context of 1 Chronicles 16 (following upon the defeat of the Philistines recounted in chapter 14), Psalm 96 accompanied the return of the Ark to Jerusalem and thus it became associated with God's act of restoration towards his people. Although the Edict of Amboise did not, as was previously pointed out, secure to the Huguenots everything they were striving for, it did relieve them from many of the hardships they had lately experienced. This was duly recognised by Le Jeune when he referred to the ensuing peace as something 'que le bon Dieu a fait tant de grace a la france ...' ${ }^{25}$

Having established a context between the historical developments in France leading to the Edict of Amboise and the particular choice of Psalm 96 as the opening piece of the Dix Pseaumes, it now stands to reason that one should also consider the election of the remaining texts, suspecting a similar involvement. First of all, the non-sequential order of the psalms cannot be accepted as unintentional. It rather suggests a deliberate concept, the rationale of which seems to lie in the presentation of certain topics by means of the different psalms and their interpretation according to Reformed exegesis. Ignoring numerical rank, these have been appropriately spaced to establish a meaningful concatenation providing also for restatements.

\section{The rest of the Dix Pseaumes}

The specific topics postulated in the psalms following upon the opening piece are highly notable, since they very much reveal the same kind of involvement and identification we have encountered in Psalm 96. Supported by Calvin's commentary on the Psalms ${ }^{26}$ (representing authentic Reformed interpretation of that time), we can summarise the subject-matter of the Dix Pseaumes as follows:

1. Psalm 96 - An exhortation to praise God, directed not only at the Jews, but also to all Gentiles, alluding thereby to the Kingdom of Christ. For until he was manifested to the world, his name could not be called upon elsewhere than in Judah. Meanwhile, the Holy Spirit stirred up the faithful to sing the praises of God, until Christ, enlightening all corners of the world with his glory, extended the light of the true doctrine even thither also. (Calvin 1610:450 seq.) ${ }^{27}$

2. Psalm 102 - In the Babylonian captivity the faithful sorrowfully and humbly bewail their afflictions; they also commend the restitution of the holy city and

25.Dix Pseaumes: Letter of Dedication.

26.The commentary first appeared in Geneva in 1557; a French translation appeared in 1558, and another one, deemed to be more faithful to the original Latin, in 1561. See Wulfert de Greef (2008:88).

27.loannis Calvin (1610:450 seq.). The italics in this and the following summaries are mine. 
the temple of God, reminding themselves of God's promises concerning the happy setting up again of both the Kingdom and the priesthood. Interposing a brief complaint concerning their sorrowful and miserable state, they seek comfort at God's everlastingness because, adopting his servants to a better hope, he has separated them from the common lot of men. (Calvin 1610:464 seq.)

3. Psalm 135 - An exhortation to sing God's praises because he had vouchsafed singular grace to his chosen people and because his mighty power and glory appear in the whole world; an antithesis is added between idols, which are vain counterfeits of the godhead, and the God of Israel, who, by assured and evident testimonies, had proved himself to be the true and only God. (Calvin 1610:627 seq.)

4. Psalm 88 - It contains the bitterest complaints of a man most piteously afflicted and (like Job) almost on the point of despair, yet showing invincible steadfastness of his faith; the whole Church is called to witness this. (Calvin 1610:411 seq.)

5. Psalm 57 - David declares his own grief and calls to God for help against Saul and the rest of his enemies (there is a pertinent reference to 1 Samuel 24 , which recounts David sparing Saul's life); having conceived hope of deliverance, he addresses himself to pay sacrifice to God. (Calvin 1610:272 seq.)

6. Psalm 98 - Similar to Psalm 96, it is an exhortation to praise God who has preserved his Church on account of which salvation will rise up to the whole world. (Calvin 1610:456 seq.)

7. Psalm 149 - Deals with the restoration of God's people and his benefits towards the Church: that the faithful might hope for continual rest under the protection of God; also, that they shall be assured with weapons and power to keep off their enemies and to chase them far and wide, subduing the kings and nations to whom they themselves had been vassals before. (Calvin 1610:672-673 seq.)

8. Psalm 95 - An exhortation to praise God because by his power he maintains the world which he had created, and also because he had freely adopted the Church to himself; therefore the people must devote themselves sincerely, earnestly, and wholly unto God, and testify by their life that they are not elected in vain. (Calvin 1610:466 seq.)

9. Psalm 97 - Also describes the kingdom of God, such as it was yet manifested under the law; thus it is a prophecy of Christ's kingdom which shone forth suddenly by means of the Gospel; God is adorned by such greatness and glory ${ }^{7}$ that it compels all men to humility, ${ }^{7}$ causing them to feel a love and favour to God's kingdom which tends to no other end than the welfare and salvation of men. (Calvin 1610:453 seq.)

10. Psalm 81 - Exhorts the people, delivered by the hand of God and chosen to be royal priesthood, and peculiar Church, to faithfully worship their deliverer in remembrance of his inestimable grace, as well with praises as with holy life. Upon this follows (in the person of God) an upbraiding of the people's unkindness, namely that whereas he allured them gently unto him, they, nevertheless, wilfully refused the yoke of his law. (Calvin 1610:386 seq.)
Placed within an eschatological framework by references to the kingdom of Christ (Pss 96, 97), the texts were evidently chosen to mirror a well-defined consciousness of the French Protestants' particular existential situation, in the context of which allusions to universality and nationalism serve their claims to confessional and political currency. Thus they saw themselves in 'Babylonian captivity', commending the deliverance and restoration of the kingdom and the priesthood according to God's promises (Ps 102). They are his chosen people (Ps 135), in deepest affliction and on the point of despair, yet invincibly steadfast in their faith (Ps 88), calling out to God for help (Ps 57). In a wondrous and incredible manner God has preserved the Church and all the earth shall see his salvation (Ps 98). The faithful can now hope for rest under God's protection, whilst they are also furnished with power and arms to keep off their enemies and even chase and subdue those who had been their oppressors (Ps 149). Because God maintains the world by his power, and since he had freely adopted the Church to himself, the faithful are admonished to godliness (Ps 95).

Summing up, the last psalm (81) once again exhorts the people to praise God: seeing that they were delivered by his hand, chosen to be royal priesthood and peculiar Church, they should, in remembrance of this inestimable grace, faithfully worship their deliverer with praises and with holy life; then follows, in the person of God, an upbraiding of the people's unkindness, namely, that whereas he allured them gently unto him, he could not succeed with them, since they wilfully refused the yoke of his law. Thus the obstinate disobedience of the people is blamed for the sad state of affairs in the country.

\section{The Mais que es-tu}

This sorrowful note is echoed in the chanson spirituelle, Mais qui es-tu, which closes Le Jeune's collection and explains, at the same time, the appendage of this piece.

Divulging as Le Jeune's choice of texts for his Dix Pseaumes and circumstances incidental to this may be, it is yet more emphasised by the association of Theodore de Bèze with the chanson spirituelle Mais qui es-tu, intentionally added to this collection. In fact, one is led to believe that its inclusion testifies to a definite collaboration between the composer and the poet. Curiously enough, there was initially some confusion about the source of Mais qui es-tu.

Thus, according to Kenneth Levy, the text of this dialogue had its origin in an epigram called La Religion by the Catholic poet, Jean Vauqelin de la Fresnaie (ca. 1535-1607), dedicated to the Duc de Joyeuse: ${ }^{28}$

Quelle es-tu, di le moy, si pourement vestue? Je suis Religion, fille de Dieu connue.

Pourquoy l'habitat as-tu d'une si poure laine? Pour ce que ie meprise une richesse vaine.

Quel Liure portes-tu?

28.From Epigrammes a Monseigneur le Duc de Joyeuse. 
Les loix de Dieu mon pere.

Ou de ses testaments est compris le mystere.

Pourquoy 1'estomac nu?

Decouurir la poitrine

Conuient a moy qui veux une blanche doctrine.

Pouquoy sur cette Croix t 'appuy-tu charitable?

La croix $m$ 'est un repos qui $m$ 'est fort agreeable.

A quelle fin es-tu de ces allies pourueue?

I 'appren l'homme a voller au dessus de la nue.

Pourqouy si rayonnente es-tu de belle flames?

Les tenebres ie chasse au loin des saintes ames.

Pourquoy ce mors Bride?

$$
\text { Afin que par contrainte }
$$

I'arreste la fureur de l'ame en douce crainte.

Et pourquoy sous tes pieds foulles tu la Mort blesme?

A raison que ie suis la mort de la mort mesme.

(Travers 1870:648)

Levy (1955:59-62) suggests - and at the time it seemed to be a plausible explanation - that it was probably written in the later 1550s, that a 'paraphrased version' was used by Le Jeune, and that it must date from about the same time or the early 1560s, when the religious troubles erupted violently. This would therefore explain why, in the text of Le Jeune's setting, Religion's robe is torn, though she is just poorly dressed in Vauquelin's poem. Levy maintains that it is not clear how this poem (supposedly Vauquelin's) came to be used at all by Protestants. ${ }^{29}$ Also John Hamersma (1960:137) in his study on the Dix Pseaumes offers no explanation in this regard. The truth of the matter is that both these authors failed to recognise Theodore de Bèze as the poet behind Mais qui es-tu used by Claude Le Jeune and Pascal de l'Estocart (also a Huguenot) - the latter who actually styled the title of his setting Dialogue sur la way Religion ${ }^{30}$ - and that this poem was the original and not a 'paraphrased version'!31

The surprising facts behind the story - for which I am indebted to Marc Honegger (1957:135), who, for his part, relied on an article by Charles L. Frossard (1884:137) - are the following: the origin of Mais qui es-tu can be traced to a youth work by de Bèze, entitled Descriptio Virtutis, which appeared in a collection of poems called Theodora Bezae Veselii Poemata, published by Conrad Badius in Paris in the year 1548:

\section{Descriptio Virtutis}

Quaenam tam lacero vestita incedis amictu?

Virtus antiques nobilitata Sophis...

However, after his conversion, De Bèze rewrote this poem. Now entitled Religio, it eventually assumed a place amongst the Icones in Theodori Bezae Poematium, editio secunda, ab eo recognito, published by Henri Estienne (no place mentioned) in 1569:

\section{Religio}

Quaenam tam lacero vestita incedis amictu?

Religio summi vera Patris soboles...

29.The 'paraphrased form' was set to music twice, the second time by Pascal de L'Estocart, as an appendix to his Cent cinquante pseaumes de David ..., published by Eustache Vignon, Geneva, 1583.

30.One notes the significant insertion of the adjective.

31.See Pidoux (1962:146, 165-166), sure enough mentions de Bèze as the author, but, unfortunately, he neither motivates his statement nor reveals any source to substantiate it.
A French translation of this poem (in the form later used in the previously mentioned musical settings) seemed to have appeared in the Confession de la Foy Chrestienne by Theodore de Bèze (see De Bèze 1560, 1561, 1563). Curiously enough, the edition of this work published by Badius in $1559^{32}$ contains neither Mais qui es-tu nor the engraving which later on regularly accompanies the poem. Our first trace of it in its now generally accepted form comes from an Italian translation: Confessione della Fede Christiana, published by Fabio Tedesco (without mention of place) in $1560 .{ }^{33}$ Here the title clearly indicates De Bèze as author: Pittura della Religione, non del Papa, ma vera Evangelica ... fata per M. Theodoro Beza Vezelio, Latina e tradotta in volgare Italiano. Two other editions of the Confession - those published by Jean Durand in $1561^{34}$ and $1563^{35}$ - also contain the poem together with the engraving, however, without any reference to the name of the author. The French translation of de Bèze's original runs as follows:

Mais qui es-tu (dy moy), qui vas si mal vestue

$N$ 'ayant pour tout habit qu'une robe rompue? Je suis Religion et n'en sois plus en peine Du pere Souverain la fille souveraine.

Pourquoy t'habilles-tu de si povre vesture? Je mesprise les biens et la riche parure.

Quel est ce livre-là que tu tiens en la main? La souveraine loy du Pere Souverain.

Pourquoy aucunement n'est couverte au dehors

La poitrine aussi bien que le reste du corps?

Cela me sied fort bien à moy qui ay le cour Ennemi de finesse et ami de rondeur.

Sur le bout d'une croix pourquoy t'appuyes tu? $C$ 'est la croix qui me donne et repos et vertu.

Pour quelle cause as-tu deux aisles au costé? Je fay voler les gens jusques au ciel vouté.

Pourquoy tant de rayons environnent ta face? Hors de 1'esprit humaine les tenebres je chasse

Que vent dire ce frain? Quej'enseigne à dompter Les passions du coeur et à se surmonter.

Pourquoy dessous tes pieds foules tu la mort blesme? Pour autant que je suis la mort de la mort mesme.

It is, therefore, clear that it was La Fresnaie's version which was paraphrased from the original poem by de Bèze and not the other way around! La Fresnaie's less 'harsh' adaptation can be explained by certain courtly conventions as to elegance and urbanity (even in tragic matters such as those referred to in the poem), whilst the poignancy of de Bèze's Mais qui es-tu accounts very well for the eruption of the religious troubles experienced at first hand. Be that as it may, the possibility should not be excluded that Le Jeune's first acquaintance with the poem could have been by way of the Italian translation, keeping in mind that the publication of that version falls within the period of his assumed Italian sojourn (Potgieter 1989:40 seq.). The form he eventually used is, however, that from Durand's editions of the Confession 32.Library of the Sociéte d'Histoire du Protestantisme francais, Paris: $R 15860$. 33.Fonds Andre 532.

34. $R 13449$.

35.R 3316 . 
of de Bèze, which could have reached him through the publications of 1561 or 1563 respectively, or which he could have obtained in a more direct way from de Bèze himself (Potgieter 1989:56-57)

It is known that the answer to the question why Catholics availed themselves of an originally Protestant poem lies in the apologetic nature of an age marked by strong claims and counter-claims, and with the respective parties by all means in possession of an acute sense for propaganda. Neither one of the religious factions was above employing an idea originally generated by the opposition once its effective qualities were recognised and necessary adaptations made to conform to the home opinion. In fact, this was considered part of the current dialectics. Susanne un jour, by the Protestant poet Guillaume Gueroult, is another example of a well-known text which was used in a similar way by both Huguenot and Catholic composers (Levy 1953:375-408). Le Jeune, by the way, made two settings of this chanson spirituelle, which were published in 1572 and 1585 respectively. ${ }^{36}$

\section{Conclusion}

A discussion of the musical propensities of the Dix Pseaumes does not fall within the scope of this article. ${ }^{37}$ Let it suffice to say, therefore, that Le Jeune, in the vein of true musical humanism, was genuinely concerned with explicatio textus and, in order to attain this, applied an extensive range of compositional techniques. To this I should add that I have rarely found his music 'neutral' with respect to text, and have come to realise that, as he progressed with the passage of time, he had more than the current madrigalesque effects in mind. For madrigalisms are mere affectations, derived, it is true, from the Humanists' attitude towards the lingual disciplines and introduced by the Italian aptitude towards histrionic gestures and playfulness, whereas text interpretation with Le Jeune seldom bears suggestions of artificiality. It is more an integral part of his musical parlance, the music itself becoming a kinetic language in its own right, ever so subtle, but infinitely more potent in expression.

As a matter of fact, one observes a shift from the grammatology of musical text expression to the domain of musical morphology. This is, ontologically, a marked difference in approach, resulting in a liberation of music from direct verbal bonds, yet expressing the sentiment of a text, and often 'saying' more than is conveyed by the mere words! If this fact is overlooked, one may indeed (as happens quite often) find 'no madrigalistic propensity' in his writing. But this does not mean 'neutrality'! Indeed, this particular idiosyncrasy of Le Jeune's musical language can already be seen emerging in his Dix Pseaumes of 1564. In later years it became firmly established and refined, heralding, as it did, Claude Le Jeune as a singularly progressive composer

36. Mellange de Chansons tant des vieux autheurs que des modernes, a cinq, six, sept et huict parties, Adrian Le Roy et Robert Ballard (1572) and Le Jeune (1585).

37.This is dealt with by John Hamersma (1960) and expanded in Potgieter (1989). in a truly modernistic sense, which elevated him, head and shoulders, above his peers.

In closing, it would, within the parameters of our present deliberations, also be inappropriate to enlarge upon the musical features of the dialogue Mais qui es-tu, interesting as this may be. However, although other commentators found the piece devoid of any manifest interpretation of text (cf. Hamersma 1960:140; Levy 1953:68), ${ }^{38}$ it must be emphasised that the music of Mais qui es-tu is every bit as eloquent as Le Jeune meant it to be. In fact, the music continues to reveal a particular concern for the interpretation of text, to the extent that the so-called devices he employs become part of his musical parlance, integrated with it, rather than remaining exterior decorations. It is for us to recognise this and read his 'language' correctly. For sure, the number of musical references to the Genevan melody of the penitential Psalm 51 (1551) to be found in Mais qui es-tu is certainly more than noteworthy, tying up, as it does, meaningfully with the closing sentiment of the Dix Pseaumes and the intent of its authors, Claude Le Jeune and Theodore de Bèze.

\section{References}

Calvin, I., 1610, Ioanni Calvini Commentarius in Librum Psalmorum, Apvd Joannem Vignon Genève.

De Bèze, Th., 1552, Pseaumes octante trios de Dauid miz en rithme François e. A scauoir, quarante neufpar Clement Marot auec le Cantique de Simeon et les dix Commandemens. Et trente quatre par Theodore de Besze de Vezelay en Bourgogne..., Jacques Berfon, Genève.

De Bèze, Th., 1554, Octante trios Pseaumes de David, mis en rime François: A scavoir Quaranteneuf par Clement Marot, auec la Cantique de Simeon \& les dix commandemens: Et trente quatre par Theodore de Beze. Auec Six Pseaumes traduicts de nouueau par leditde Besze..., lean Crespin, Genève.

De Bèze, Th., 1559, Confession de la Foy Chrestienne, Conrad Badius, Genève. (Library of the Société d'Histoire du Protestantisme francais, Paris, R15860.)

De Bèze, Th., 1560, Confessione della Fede Christiana, translated from the French into Italian (Pittura della Religione, non del Papa, ma vera Evangelica... fata per $M$. Theodoro Beza Vezelio, Latina e tradotta in volgare Italiano), s.l., Fabio Tedesco. (Library of the Société d'Histoire du Protestantisme francais, Paris, Fonds Andre 532.)

De Bèze, Th., 1561, Confession de la Foy Chrestienne, Genève, Jean Durand (Library of the Société d'Histoire du Protestantisme francais, Paris, 13449).

De Bèze, Th., 1563, Confession de la Foy Chrestienne, Genève, Jean Durand (Library of the Société d'Histoire du Protestantisme francais, Paris, R3316).

De Bèze, Th., 1580 [1883], Histoire ecclesiastique des eglises reformees au royaume de France, 3 vols., Jean Remy, J.G., Baum, E. Cunitz \& R. Reuss (ed.), Fischbacher, Paris.

De Tou, J.A., 1734, Histoire universelle... depuis 1543 jusqu 'en 1607, 16 vols., (Londres) Paris.

De Greef, W., 2008, The Writings of John Calvin, Westminster John Knox Press, Louisville.

Doumergue, E., 1899-1927, Jean Calvin: Les hommes et les choses de son temps, 7 vols., Georges Bridel, Lausanne.

Frossard, Ch.L., 1884, 'L'emblème de la religion réformée et le Portrait de la vraye religion', Bulletin de la Société d'Histoire du Protestantisme francais, vol. XXX (1881), pp. 174-182

Haag, E. \& Haag, E., 1859, La France Protestante, vol. VI, J. Cherbuliez, Paris.

Hamersma, J.E., 1960, Les Dix Pseaumes of Claude Le Jeune. A study in 16th Century French Psalmody, vol. I, (S.D.M.) thesis, Union Theological Seminary, New York.

His, I., 2000, Claude Le Jeune (v. 1530-1600). Un compositeur entre Renaissance et baroque, Actes Sud, Arles.

Honegger, M., 1957, Contribution in the Bulletin de la Societe d'Histoire du Protestantisme francais, vol. CIII, 135.

Le Jeune, C., 1564, Dix Pseaumes de David, novvellement composez a qvatre parties en forme de motets. Auec vn Dialogue a scept, ..., Adrian le Roy et Robert Ballard, Paris. (compl. Paris, Bibl. Ste-Genevieve: Res. Vm48.)

Le Jeune, C., 1585, Livre de Melanges de C. Le leune, De l'Imprimerie de Christofle Plantin, Anvers.

Le Jeune, C., 1598, Dodecacorde contenant douze Pseaumes de David, mis en musique selon les douze modes approuvez des meilleurs Autheurs anciens \& modernes a 2.3.4.5.6. et 7 voix. Par Claud. Le leune, Compositeur de la musique de la Chambre du Roy, Hierosme Haultin, La Rochelle.

38. His (2000:312) is mainly concerned with word-rhythm (... Mais qui es-tu ...., qui termine le recueil de 1564, temoigne de la relative indifférence prosodique qui caractérise encore la polyphonie). 
Le Jeune, C., 1606, Pseaumes en Vers mesurez mis en musique a 2.3.4.5.6.7. \& 8 parties. Par Claude Le leune, natif de Valentienne, Compositeur de la Musique de la Chambre du Roy. Pierre Ballard, Paris.

Levy, K.J., 1953, 'Susanne un jour - The history of a 16th century chanson', Annales musicologiques, Paris, (I), 375-408.

Levy, K.J., 1955, 'The chansons of Claude Le Jeune', Ph.D. thesis, Princeton University, Princeton.

Marot, C. \& De Bèze, Th., 1562, Les Pseaumes mis en rime Françoise, Par Clement Marot, \& Theodore De Bèze, Pseaume IX, Chantez au Signeur qui habite en Sion, \& annoncez ses faits entre les peuples ... François Jaquy, Genève, 1562; Les cent et cinquante Pseaumes de David, mis en ryme Françoise: c'est a scavoir, quaranteneuf par Clement Marot, \& le surplus par Theodore De Bèze, ... Richard Breton, Paris.

Mellange de Chansons tant des vieux autheurs que des modernes, a cinq, six, sept et huict parties, 1572, Adrian Le Roy et Robert Ballard, Paris.

Moreri, L., [1674] 1716, Le grand dictionnaire historique, vol. IV, Girin \& Riviere, Lyon.

Naef, H., 1922, La conjuration d'Amboise et Genève, Jullien, Genève.
Nürnberger, R., 1948, Die Politisierung des französischen Protestantismus: Calvin und die Anfänge des protestantischen Radikalismus, J.C.B. Mohr, Tübingen.

Pascal de L'Estocart, 1583, Cent cinquante pseaumes de David ..., Eustache Vignon, Genève.

Pidoux, P., 1962, Le Psautier Huguenot du XVIe Siecle, Bärenreiter, Bâle.

Potgieter, J.H.L.S., 1989, 'The initial years (ca. 1528-1565) of Claude Le Jeune: Huguenot and musical humanist', Ph.D. thesis, Rhodes University.

Travers, J., ed., 1870, Les diverses poësies de Jean Vauquelin Sieur de la Fresnaie, vol. II, Epigrammes a Monseigneur le Duc de Joyeuse, Caen.

Vannes, R., n.d., 'sv. Claude le Jeune', in Dictionnaire des musiciens, Bruxelles, p. 239.

Von Ranke, L., 1957, Französische Geschichte vornehmlich im 16. und 17. Jahrhundert, 2 Bände, in W. Andreas (ed.), Historische Meisterwerke, Standard Verlag, Wiesbaden/Berlin. 